\title{
Poor Performance in National Examinations by Public Primary Schools in Kakamega North Sub-County, Kenya
}

\author{
Eric W. Wamalwa \\ Department of Kiswahili \& Other African Languages \\ Kibabii University, Kenya \\ County Quality Assurance and Standards officer \\ Laikipia County \\ Felix A. Mugasia \\ William K. Sugut \\ County Director of Education \\ Nakuru County, Kenya
}

\begin{abstract}
Great importance is attached to basic education in Kenya. Article 53. (1) (b) of the Constitution of Kenya (2010) states that every child has a right to free and compulsory basic education. Consequently, great importance is attached to performance in the national examinations, which mark a transition from primary to secondary level education. Examination results remain the major way of not only measuring acquisition of knowledge but also determining those who transit to the next level and the quality of schools to be joined by the pupils. Despite the emphasis placed on performance, many pupils in the country continue to post very poor results in national examinations. Given the above, this study set out to determine some of the factors that contribute to poor performance in national examinations at the primary school level. This study was conducted in selected schools of Kakamega North Sub-county. A descriptive survey was used in conducting the study. The participants were head teachers, Boards of Management chairpersons and teachers who oversaw examinations. Open-ended questions were used to provide the required information. Content analysis was also used to analyze provided information. Three main categories of factors were identified as heavily impacting pupils' performance, viz; parental factors, school leadership factors and factors associated with staffing of teachers. The study recommends the adoption of a multi-sectorial approach to solving problems bedeviling primary education in the sub-county.
\end{abstract}

Keywords: Basic education, academic performance, public primary schools

\subsection{Introduction}

Education is considered by various stakeholders, not only as a basic need but also a basic right. In evaluating whether pupils have acquired education, performance ranks high on the national agenda with educators and policy makers focusing on testing, accountability, curriculum reform and teachers' quality, school choice and other related concerns (Reche, Bundi Riungu and Mbugua (2012). The government of Kenya provides funding through both School Instructional Materials Bank Account (SIMBA) and General-Purpose Account (GPA) for purposes of procurement of learning resources and infrastructure improvement-all aimed at improving the quality of education. In addition to Free Primary Education (FPE), the government has funded the education sector through the Constituency Development Fund (CDF). By the end of the 2014/2015 financial year, it was estimated that Kakamega North sub-county public primary schools would have gobbled up 81.36 million Kenya shillings in FPE funding.

If examinations are a valid measure of achievement as it is generally accepted according to (Maiyo \&Ashioya 2009), then this sub county's achievement has been dismal. Secondary school placement has for along time depended on the performance of Kenya Certificate of Primary Education (henceforth KCPE). This has disadvantaged many candidates from the sub-county as only very few of them have made it to the prestigious national and extra county schools. Many have ended up being admitted to the local public secondary schools where their performance has continued to be wanting.

Before the creation of counties, Kakamega North was always ranked the last in KCPE examinations in the western province. The situation has not changed even after the creation of counties. Since 2010, the sub-county has always been ranked last in KCPE examinations. 
For instance, in the $2014 \mathrm{KCPE}$ exams, the sub-county was ranked the $12^{\text {th }}$ out of 12 sub-counties that make up Kakamega County, with a performance index of 243.53marks, which was a drop from the previous year's mean mark of 248.74. In the $2014 \mathrm{KCPE}$ exams, only $10(0.19 \%)$ candidates out of 5207 candidates scored above 400 marks while $328(6.3 \%)$ scored below 100 marks. This downward trend is captured in the table below.

Table 1.0: Kakamega North sub county's performance index in KCPE from 2012-2017

\begin{tabular}{|l|c|c|c|c|c|c|c|}
\hline Year & Candidature & English & Kiswahili & Mathematics & Science & $\begin{array}{l}\text { Social } \\
\text { studies }\end{array}$ & Mean \\
\hline 2017 & 6005 & 48.83 & 57.76 & 49.71 & 49.70 & 49.97 & 251.94 \\
\hline 2016 & 5338 & 50.05 & 54.06 & 46.59 & 49.86 & 49.96 & 251.59 \\
\hline 2015 & 5331 & 49.58 & 53.38 & 48.82 & 50.09 & 51.59 & 254.69 \\
\hline 2014 & 5207 & 49.74 & 49.74 & 48.0 & 43.39 & 49.09 & 243.53 \\
\hline 2013 & 5069 & 50.17 & 53.49 & 47.75 & 48.66 & 49.73 & 248.74 \\
\hline 2012 & 4953 & 49.53 & 52.44 & 47.73 & 47.61 & 49.13 & 245.53 \\
\hline
\end{tabular}

(Source: Sub County Education Office: 2017)

From the above table, the following can be deduced:

i. The candidature in the sub-county is on the increase,

ii. The performance index of the sub-county shows no marked improvement,

iii. The average performance index of the Sub-county for all the five subjects is below the 250 pass mark.

From the aforementioned, it is evident that the performance situation in national examinations for primary schools in the sub-county is dire and needs to be addressed urgently so as to avert a further drop. Therefore, main objective for this study was to identify factors that contribute to poor performance in national examinations in Kakamega North Sub County.

\subsection{Literature Review}

Various factors have been cited to account for poor academic performance among students at both primary and secondary levels. For purposes of this study, these factors may be classified in to the following categories:

i. Socio-economic factors

ii. Leadership and administration factors

iii. Policy and management factors

\subsection{Socio-economic factors}

A host of factors impacting negatively on pupils' performance are socio-economic in nature. Studies have identified the home environment as being a big impediment to academic performance. Factors within the home environment such as the role of parents in the academic endeavors of their children i.e. parental influence, the study environment at home, the socio-economic status of parents and family size impact negatively on performance (Ferguson, 1991; Hammer, 2003; Phillips 1998). This is clearly manifested in families where, if the parents are socially, educationally and financially advantaged, it is likely to foster a high achievement in their children. Likewise, pupils from high social economic backgrounds have a higher probability to be well exposed to scholastic materials, which are critical in enhancing high achievements. It may be argued here that in most African countries, Kenya included, socio-economic factors have the greatest influence on the academic performance of pupils. This study therefore assesses host of factors impacting the academic endeavors of children in Kakamega North sub-county.

\subsection{Leadership and administration factors}

School leadership is key to good academic performance. Defined as the ability to get things done with the assistance of other people in the institution (Adesina, 1980), leadership is the process of influencing the activities of an organized group towards goal setting and goal achievement. Through leadership, mechanisms for planning, goals setting, coordination and implementation of programs is done, which leads to goal achievement in an organization. In primary schools, the head teacher is charged with this great role. Therefore, the active leadership of the head teacher is seen as important for school improvement in general and the essential ingredient of educational reform (Purkey \& Smith, 1983). As a leader, the head teacher should ensure that other effective factors are put in place. This can be done through partnerships with other stakeholders like parents and teachers through the Parents' Teachers' Associations (PTA's) and by collaboration with ministry officials in attaining the set objectives.

Leadership affects both the physical and human resources in institutions of learning. For instance, the following factors which are known to affect academic performance are more likely to exist in an environment with poor leadership: 
poor educational facilities, lack of instructional materials, use of traditional methods of teaching, large pupils to teachers ratio, lack of teaching equipment and materials such as laboratory equipment and chemicals, poor motivation of teachers and pupils, and lack of teacher preparedness and readiness to teach (Akpan, 1987; Odogwu, 1994; Oshibodu, 1988; Williams, 1988). Research on leadership has previously supported the importance of the head teacher in guiding school reform and improving student achievement. This study has sought to establish how the school head teacher as a component of school administration influences academic performance in primary schools in Kakamega North sub-county.

\subsection{Policy and Management factors}

In Kenya, it is the role of the Ministry of Education, Science and Technology to formulate policy and oversee its implementation on matters of education. Matters dealing with staffing, transfer and posting of new staff to schools are handled by the Teachers Service Commission (TSC) on behalf of the ministry. Schools that are well staffed have a favorable pupils'-teachers' ratio, a result of which improves instructional supervision. AsKose (2007) has correctly pointed out, instructional supervision is critical for effective teaching and learning processes. It is therefore, a major factor that influences pupils' performance in academic exercises, (Pansiri \& Dambe, 2005). This is to say that instructional supervision aims at improving instructional and learning outcomes.

Since the inception of Free Primary Education (FPE) in Kenya in 2003, the government has not matched the number of teachers to the number of pupils admitted to primary schools. Thus, the policy of free education to the Kenyan child has succeeded in granting her access, but failed to provide her with quality education. In many Kenyan primary schools, pupil numbers have impacted negatively on the few available instructional materials. The role of instructional materials in enhancing teaching and learning cannot be over emphasized. Lack of instructional materials during a lesson or its inadequate provision poses a great learning challenge to the learner. Substantial access to these resources contributes to the teachers' and learners' competence in making use of them, which remains an exception given the challenges related to access and availability to both students and teachers in schools (Wamalwa \& Wamalwa, 2014). With the soaring numbers and little financial support from the government, most schools cannot afford to build and equip libraries yet studies show that there exists a significant relationship between a library and pupils' academic performance (Waldman, 2003).

The policy of free access to education has had negative ramifications especially on the quality of education. The government has in the past emphasized, and continues to insist on free admission to class one and 100 percent transition rate to secondary school from primary level. It is critical to note that factors such as academic entry behavior of pupils and their educational background play a big role on their future academic well-being. As Geiser and Santelices (2007) have argued, entry behavior in terms of scores or previous grades is a pupil's reflection of the previous performance, a pointer to the pupil's academic ability. This ability in our view, is not permanently fixed. Its shift largely depends on other factors including how it is managed. If the behavior is not managed accordingly, a poor student will continue to post poor grades while a high achiever may be influenced to start posting poor grades. The focus of this study was on three main factors, and the resultant impacts these factors have on performance of class eight pupils in national examinations in Kakamega North sub-county.

\subsection{Theoretical framework}

The study was anchored by the Systems Theory Input-Output Model. According to Katz and Kahn (1966), the theory postulates that organized enterprises do not exist in a vacuum but rather, are dependent on their external environment. As a result, enterprises receive inputs, which are then transformed to out-put and are thereafter exported to the environment. It suffices here to say, that a school as an organization is an academic enterprise, and as such, it is regarded as a system. Schools are systems in which educational programs are tailored to realize the importance each sub unit contributes to the whole. As a result, there is need to eliminate or correct those elements whose contributions to the system are negative.

Due to the interactions that take place in school viz a viz between various subjects, inter and intra departmental engagements, school management and teachers - parents' interactions, a school is better investigated as a whole rather than a part. Thus, the theory postulates that schools are like other systems which of necessity engage in various modes of exchanges with the environment. The theory puts emphasis on the consideration of the relationships between the school and its environment as well as what goes on within the school. The theory focuses on the problems of associations of the structures and of interdependence (Katz and Kahn, 1966). As used in this study, this theory holds that factors which influence pupils' academic performance in a school for instance, the school management, sociocultural factors, the perception of stakeholders towards education, teaching-learning resources, socio-economic background of pupils and teaching-learning activities, all influence pupils' academic performance. 
This means that for instance, if one factor is altered, for example, the provision of teaching-learning resources, or lack of them, the academic performance is potentially affected. The education system is considered as a system which comprises of various sub-systems. In this study, we focus our attention on three elements, viz: factors that deal with parenting, factors associated with school leadership and factors associated with management of education at the Subcounty's office, which are considered as a set of interrelated, though separate entities which impact on pupil performance in national examinations.

\subsection{Methodology}

A descriptive survey was used to conduct the study. The participants were 65 head teachers, 65 Board of Management chairpersons and 65 teachers who were in charge of examinations in their respective schools. Questionnaires bearing open-ended questions were administered to solicit the information required. Focus group interviews were also held with the three groups. Content analysis was also used to get information from secondary sources. Documents that were analyzed included Standards Assessment reports, previous years' County and Sub-county performance indexes. Qualitative data obtained from open ended-questions and contents analyses was organized into categories and themes pertinent to the study.

\subsection{Findings and discussion}

\subsection{Factors associated with Parenting}

These are factors that could have been addressed at the homes of the learners by their parents or guardians. However, due to unexplained reasons, they were not addressed thus providing a gap between the school and home.

\section{a) Absenteeism}

Most teachers and heads cited absenteeism of learners from. It was clear that while students absented themselves from school, their parents/guardians did not show keen interest in following up of the absentee cases of their pupils. In some cases, it was revealed that, it is the parents who encouraged their children not to attend school regularly by assigning them duties to perform at home. Some of these duties included looking for manual jobs to supplement the family income. Therefore, some pupils absented themselves to go to the sugar factories to load cane on tractors; to plough land for people, plant and weed as well as to harvest cane and other crops.

When pupils returned to school after a period of being absent, it was difficult for them to catch up with what the rest of the pupils had been taught. It was also very difficult for them to complete assignments that had been given to other pupils. This was a recipe for poor academic performance Ubogu (2004). It was also revealed that many parents were neither bothered by the number of days their children were absent from school, nor were they interested in their academic performance in school. Moreover, when the schools required parents for academic days, only few parents turned up. For instance, in one school in the Sub-County, when parents were invited for a class 7 academic meeting, only 4 parents out of the expected 60 parents turned up for the meeting.

In some cases, when candidates were through with KCPE registration process, they temporarily left school only to reappear during the rehearsals for examinations in November. Given that they had not learnt anything for the while they were to be out of school, they ended up failing the examination. There were records in schools that revealed that those who disappeared from school after registering in March and returned in November only to sit for the examinations performed dismally.

\section{b) Lack of provision of food}

Some parents and guardians did not provide food for their children to eat at home. Consequently, some pupils went to school on empty stomachs in the morning. They only relied on lunch that the school provided to them. A perusal of the Standards Assessment reports of some primary schools indicated that the lunch which the schools provided for learners was the only meal eaten by the learners as some of them did not eat anything else at home. As this was being reported, some of the parents were also unwilling to contribute to the lunch kitty in schools yet they had the ability to do so. This made many hungry pupils not to concentrate on their class work. Reche et al (2012) indicated that hunger among learners influences academic performance negatively.

\section{c) Sickness as a cause of absenteeism}

Some students were absent from school due to sickness. Peculiar to this sickness was the fact that some of parents did not believe in taking their children to hospital because they belonged to certain cultic groups that did not recognize, and therefore do not believe in conventional medication. Records showed that during $2014 \mathrm{KCPE}$, the education office rescued one candidate whose parent had kept her at home due to sickness and was unwilling to take the child to hospital for medication. 
In September 2014, the Ministry of Education, Science and Technology in conjunction with the Ministry of health organized for a de worming exercise in the sub county. All children between the ages of 2-14 were to be de-wormed using the Albendazole ${ }^{1}$ tablets. Parents in some areas were resistant to this exercise yet it was beneficial to their children.

\section{d) Retrogressive religious practices}

These were cited as a factor that had negatively impacted performance. The practices were said to be crippling in into primary schools in the Sub-county. Cases have been reported in the past of pupils behaving hysterically (an occurrence assorted with the demonic influence) while in school. Five (5) primary schools reported having dealt with such cases of religious practices and claim edit affected the candidates in the school in that affected pupils were not able to concentrate on their academic work which resulted in poor performance in national examinations.

\section{e) HIV/AIDS pandemic}

The pandemic has caused havoc to many homesteads in the sub-county. This was especially in homes near the two sugar factories: Butali and West Kenya. One School reported that out of a population of 960 pupils; 340 were total orphans while 310 were partial orphans. The affected children were staying with guardians/relatives some of whom were not well endowed. Many of these children lacked the basic needs for them to concentrate in class.

\section{f) Boy/Girl relationships}

These relationships were rampant in the mixed day schools in the Sub-County. This affected learning negatively in that many girls were forced to drop out of school prematurely. For those who returned to school after delivery, they could not concentrate on their class work as they were constantly thinking about their babies. Moreover, the other pupils mocked them while in school, an occurrence which impacted their self-esteem negatively. One of the schools that performed dismally in KCPE reported that out of the 36 candidates it registered for KCPE 10 girls (below the age of 15) were mothers and most of the time was absent breastfeeding their children. In some of the cases of boy/girl relationship that resulted in unwanted pregnancies, the parents of the girls were not interested in being assisted to take legal action against the male persons concerned.

\subsection{Factors associated with School Leadership}

From discussions held with school leaders, it was revealed that school leadership was also to blame for poor performance in KCPE in the sub county. There were some schools where head teachers were not good role models to other teachers. They did not have a lesson in the candidate class and therefore could not encourage other subject teachers in the candidate classes. This agreed with findings of standards assessment reports that revealed that very few Primary School head teachers in the Sub-County were effective classroom teachers. The few who taught had subjects in lower or primary where teaching was perceived not to be very rigorous.

It was also revealed that head teachers neither monitored nor supervised curriculum implementation in the schools. In most schools, syllabus coverage was poor. The head teachers did not realize that there was poor syllabus coverage in most subjects in their schools as they neither monitored nor supervised the curriculum. Some of the head teachers in the primary schools did not attend school regularly. They were also absentee head teachers who managed their schools using the mobile phone. Some of the head teachers appeared in school once or twice in a week thus teachers were left to do what they wanted without being supervised. From the Standards assessment reports of some of the schools, the head teachers did not fill in the school log book when they were away. Some of the log books had not been filled for three consecutive months. In some schools the deputy head teachers did not know how to fill the school log books. Indeed, Odhiambo (2009) pointed out that the problem of performance was deeply rooted in management practices which must change if target goals in the education sector areto be realized.

It was revealed that the school management committees (SMCs), where the head teachers were the secretaries were not effective in some schools. Some of those committees did not discuss issues related to academic performance in their meetings. While they discussed financial issues and school infrastructure in general, academics were relegated to the periphery. There were very few schools in which the SMC demanded improved performance in academics by the schools. Moreover, despite the government policy guideline that SMC members ought to have had ' $\mathrm{O}$ ' level education, some SMC chairpersons were illiterate and did not comprehend basic principles of academic performance in schools. Some of the SMC chairpersons did not have a vision for the school, neither did they bother to interrogate the school's academic performance in their SMC meetings. They thus failed to execute their mandate in accordance to the Basic Education Act of 2012.

\footnotetext{
${ }^{1}$ Albendazole is an anthelmintic, anti- worm medication. It prevents newly hatched insect larvae (worms) from growing or multiplying in the body. Albendazole is used to treat certain infections caused by worms such as pork tapeworm and dog tapeworm. 
For some schools, the SMC members made unnecessary trips to the school not to check on academic performance but to interfere with the working of the teachers in the school. This made the operations of the school very difficult.

It was also revealed that some of the teachers' pedagogical skills were wanting. Although teachers had attended to subject-based in-service trainings (INSETS); they still employed the teacher centered methodology of teaching as opposed to the learner centered approaches. Some teachers did not prepare adequately for their lessons.

This concurred with findings of standards assessment reports that showed that teachers were ill prepared to teach their lessons whether in lower or upper primary. Most teachers did not have lesson plans, few had lesson notes while majority of the teachers did not have up-dated schemes of work. Most of the objectives for teaching the lessons plotted for on the timetables were not achieved as they were not in tandem with the syllabus books.

The fact that most teachers did not consult the syllabus books to draw their lesson objectives was an indicator of lack of commitment on the part of the teacher. According to Legotlo, Maaga \& Sebego (2002), low teacher commitment and morale is a major cause of poor academic performance. Indeed, in most schools, teachers did not take the lower primary serious. Most teachers missed lessons, were ill prepared to teach or taught what was not appropriate. Thus the foundation was weak. The same teachers concentrated on the candidate class, yet the class was not able to cope with the load that was put upon them. Even with the candidate class, the teaching methodology was not appropriate.

Lydia and Aksongo (2009) implored teachers to use appropriate teaching methodologies for effective learning. Both Atieh (1997) and Schneider (2003) highlighted the importance of teaching techniques as having a significant effect on students' performance. Commenting generally on levels of literacy and learning levels, theUwezo Report (2016) posits a very worrying scenario. For instance, the report says that on the national level, 5.5 percent of class 8 pupils cannot do class 2 mathematics, 3.8percent of class 8 pupils cannot do class 2 English while 3.1percent of class 8 pupils are not able to attempt class 2 Kiswahili work. The same comparison done on rural schools' basis, it was found out that 8percent of class 8 pupils in rural areas generally cannot manage class 2 work. If this is the case, we are left wondering how many pupils in rural areas will find difficulties with either class five, class six or class seven work, pupils in Kakamega North district not being an exception. While this is true, all these schools are under the leadership of head teachers believed to have been carefully selected among many teachers who had proved that they could head these institutions.

Most primary schools in the Sub-County did not have the recommended pupils/book ratio of 1:1 despite the FPE funding which started in 2003. It was expected that those schools that were in existence at the commencement of this funding would be having a pupil/book ratio of 1:1 given that they had received the funding for over 12 years. Most primary schools did not have adequate text books. Either the books had been bought and were stolen or they had not been bought at all. This required research to be done on how the head teachers used the vote head of instructional materials on FPE.

In the standards assessment reports of selected schools, findings revealed that the schools did not have adequate text books which hindered teachers' effective use of the texts in class. Pupils were not accessible to these books as they did not exist in the school. On the contrary, minutes of the SIMSC committee (responsible for the procurement of text books and other learning resources in the school) indicated that the required books had been ordered for. The head teachers had also prepared the Local Purchase Orders (LPOs) and given them to the school suppliers who indeed had supplied the books to the schools as evidenced by the delivery notes, invoices and the receipts issued as per normal business transactions.

Some teachers had superior qualifications in comparison to the head teachers in their schools. Thus, the head teachers feared them. Even when they did what was not right, the head teachers did not dare to face the teachers to reprimand them. This gave the teachers a lee way to do all sorts of wrong things including arriving late in school, going late for their lessons, not marking/checking their pupils exercise books and not writing and maintaining professional records. There was revelation to the effect that some of the teachers who were pursuing further studies in institutions of higher learning, performance in their subjects were wanting yet they were studying the same subjects at that higher level.

\subsection{Factors associated with the Education Office}

The District Education Office (currently known as the Sub-County Education Office) was not spared on the poor performance in KCPE. Complaints on staffing of teachers in schools emerged. It was revealed that some primary schools that presented candidates in last year's KCPE had only four teachersposted by the Teachers Service Commission (TSC) against eight streams. This number of teachers was far too in adequate to handle the teaching work load in such a school. The affected schools had to employ PA teachers to assist in the implementation of the curriculum. Some of the PA teachers were form four leavers as the schools could not afford to pay the unemployed P1 teachers. 
The form four leavers could not effectively interpret the syllabus for effective teaching. Indeed,Asikhia(2010) has pointed out that lack of qualified teachers can contribute to poor academic performance. For those that managed to employ P1 graduates, they could not manage to sustain them in the schools thus the turnover was high. Some teachers taught in the schools but their morale was low due to the low salaries that they were receiving. At times, salary payment was delayed by several months.

Some schools that did not perform well attributed their bad performance to transfer of their good teachers to other schools without replacement. One head teacher pointed out that in one year, 7 of his teachers had been transferred without any replacement and his school found it very difficult to cope with the situation.

This bordered on impartiality of the staffing office in regards to certain cases of transfer of teachers. It was also revealed that there was an unbalance of staffing in some regions in the District. While the schools in the urban centers and those along the road were well staffed, those in the rural and interior were not adequately staffed. The education office was accused of partiality in staffing of schools where schools perceived to align themselves to the office received more teachers than those that were not close to the education office.

Schools complained of lack of adequate school inspection by the quality assurance and standards office. The Subcounty had only one designated Quality Assurance and Standards Officer (QASO). The department of quality assurance and standards was grossly understaffed. Out of an establishment of 6 quality assurance and standards officers, the sub-county had only one who was manning the whole sub-county.

He was assisted by the TAC tutors in carrying out inspection of schools. Although several schools had been inspected, the frequency was low given that the department did not have a vehicle designated for inspection work. It was believed that lack of frequent visits by the QASO to the schools made the teachers to have laxity in their work thus compromising the quality of education offered. This was an indication of laziness on the side of teachers, who needed to be monitored and coerced to work for them to be effective.

\subsection{Conclusion and Recommendations}

From the research findings, the challenges affecting academic performance in public primary schools in Kakamega North sub-county are varied and cross cutting. It is evidently clear that not one sector of stakeholders is solely responsible for the current situation that obtains in the sub county. The Government of Kenya, through the Ministry of Education and specifically the department of Basic Education has the onus of ensuring that education standards are attained and maintained in all primary schools. This function of the department has not been fully actualized. Staffing of teachers, which is a function of the national government, could be improved if it were to be complemented by County governments, which have the capacity to employ teachers. The school going children in the sub county has a right to quality basic education. The situation, as is currently in the sub county does require a multi-sectorial approach if thefactors accounting for poor performance are to be surmounted. All stakeholders in the education sector of the area are called upon to form positive synergies that will ensure lasting solutions to the prevailing problems are arrived at.

\section{References}

Adesina, S. (1980). Some Aspects of School Management. Lagos: Educational Industries Nigeria Limited.

Akpan, A.A. (1987). Correlates of mathematical problem-solving ability among secondary school students. Unpublished Ph.D Thesis, University of Ibadan, Ibadan.

Allele-Williams, G. (1988). Keynote address delivered at the Silver Jubilee meeting of Mathematics Association of Nigeria (MAN) Sept. 1982, Abacus 18(1).

Asikhia O.A (2010). Students and Teachers Perception of the causes of poor academic performance in Ogun State secondary schools (Nigeria) - Implications for counseling for National Development, Lagos State: Michael Otedola College of Primary Education. European Journal of Social Sciences, 13: 238-240.

Atieh, S. H (1997). Students Perception of causes of low performance in Principles of

Accounting: A case study of South Arabia: KiongFalid University of Petroleum and Minerals. J.K.A: Econ and Adm.10:35-50.

Ferguson, R. F. (1991). Paying for public education: New evidence on how and why money matters. Harvard Journal on Legislation, 28, 465-499

Geiser, S and Santelices, V. M. (2007). Validity of high school grades in predicting student success beyond the freshman year. Retrieved on February 8, 2008 from http://cshe.berkeley.edu/publications/docs/ROPS.GEISER_SAT_6.12.07.pdf

Hammer. B (2003). ETS Identifies Affecting Students Achievement, Washington update.

Katz, D. and R. Kahn. 1966. The Social Psychology of Organizations. New York: Wiley. 
Kose, B.W. (2007). Instructional supervision: University of Illinois at Urbana Champaign,

College of Education: Department of educational organization and leadership. Retrieved from http://www.ed.uiuc.edu/eo/frp/bkose

Legtlo, M.W, Maaga M.P and SebegoM.G (2002). Perception of stakeholders on causes of poor performance in a province in South Africa: South African Journal of Education. 22(2)113-118.

Lydiah, E.M and Nasongo, J.W. ((2009). Role of Head teacher in academic achievement in secondary schools in Vihiga District. Kenya: Masinde Muliro University of Science and Technology.

Maiyo, J.A. \&Ashoya, L.A. (2009). Poverty Alleviation: The Education Planning Perspective. Department of Education Planning and Management. Masinde Muliro University of Science and Technology.

Odhiambo, R. (2009). 'Elusive search for quality Education: The case of case of quality assuranceand teacher accountability'. Int J. Education Management 22(5):417-431

Odogwu, H.N. (1994). Primary school teachers and the teaching of time concept in schools. Education Today 7:2.

Oshibodu, B.M., (1988). Mathematics at primary level. Abacus 18.1.

R. O. K. (2010). The Constitution of Kenya, 2010. Nairobi: Government Printers.

Pansiri, N.O. \&Dambe, M. R. (2005). Instructional leadership for improving commitment to Basic education for the remote area dwellers in Botswana. Faculty of Education. University of Botswana.

Phillips, M. (1998). Family background, parenting practices, and the black-white test score gap. The black-white test score gab, Washington, D.C., Brooking Institution Press.

Purkey, S. \& Smith, M. (1983). Effective schools: A review. Elementary School Journal, 83: 335-351.

Reche, G.N, Bundi, C.K, Riungu, J.N and Mbugua, Z.A (2012). Factors contributing to poor performance in K.C.P.E in public primary schools in Mwimbi Division, Maara District, Kenya, Chuka University College. Internal Journal of Humanities and social sciences. 2(5) 127-133.

Schneider,M. (2003). Do schools facilities affect academic outcomes? Washington D.C: National Clearing House for Educational facilities.

Ubogu, R.E (2004). The causes of Absenteeism and Dropout among secondary school students in Delta Central Senatorial District of Delta State: Unpublished PhD Thesis Delta StateUniversity Nigeria: Abraka.

Uwezo (2016). Are our Children Learning? Uwezo Kenya, Sixth Learning Assessment Report, Nairobi: Twaweza East Africa.

Waldman, M. (2003). Fresher's use of library electronic resources and self-efficacy. Information Research, 8, 2:202234.

Wamalwa, E. J. and Wamalwa, E. W. (2014). Towards the Utilization of Instructional Media for Effective Teaching and Learning of English in Kenya. Journal of Education and Practice, Vol.5, No.31, 140-148. 